\title{
Assessing Change in a High-Value Landscape: Case Study of the Municipality of Sobotka, Poland
}

\author{
Piotr Krajewski* \\ Department of Spatial Management, Wroclaw University of Environmental and Life Sciences, \\ ul. Grunwaldzka 55, 50-357 Wrocław, Poland
}

Received: 21 February 2017

Accepted: 3 May 2017

\begin{abstract}
This article presents analyses made in the first stage of research on determining landscape capacity of Sobotka municipality located in Lower Silesia in Poland, partially within Sleza Landscape Park and Bystrzyca Valley Landscape Park. The main objective of the study was to determine the level of change that took place in the high-value landscape of the analysed area in 1938-2016, and to identify the threat level of changes in the future. I began research by preparing maps showing the main elements of land cover for the three periods to be examined. Using of the maps, I developed a database of the surface of the main elements constituting the background landscape of the research area. I relied on available cartographic documents and aerial photographs from the years 1938, 1977, and 2014, plus field studies carried out in 2016. The data obtained made it possible to assess the level of change in two different periods by means of the landscape change index. The analysis helped identify areas where landscape changes were the highest and areas where changes were hardly noticeable. The last step was to identify to what degree the landscape is threatened with changes in the future, current spatial policy of the local authorities being the basis for it.
\end{abstract}

Keywords: landscape change, driving forces, landscape change index, landscape capacity, Poland

\section{Introduction}

Calculating landscape capacity is important for landscape planning and management. We will be able to see the changes to the area more clearly if a longer time horizon is taken into account. Especially in recent studies, measurements and aerial photographs from different time periods are used to analyze landscape changes in different computer programs [1-2]. Over the past few decades, intensification of landscape transformation can be seen due to massive socio-economic changes, for instance in agriculture, industry, and transportation [3]. Signatories

*e-mail: piotr.krajewski@upwr.edu.pl of the European Landscape Convention (ELC), including Poland, have also recognized that landscape is a key element of individual and social well-being, and that its protection, management, and planning entail rights and responsibilities for everyone. The problem of ELC implementation is currently being discussed in Poland in connection with the landscape audit, which is a new obligatory tool for landscape management [4]. One of the main tasks identified in this document is mapping transformations taking place in the landscape and determining the forces causing them. For instance, Antrop wrote about the significance of past landscapes [5], while Bürgi et al. [6] set out to identify the driving forces of landscape change. The importance of this type of research was also appreciated by Chmielewski [7], who believed 
that land-use planning should be based not only on the current structure of the landscape but also on the trends in the changes in its structure taking place in recent decades. There are many other factors that bring about landscape changes. One of them is climate change. This process in particular disturbs the natural structure of land in coastal areas. Climate in city centers also has an impact on the value of landscape space [8].

Research into landscape change has thus far been a popular study area. Transformations have been analysed in various aspects, scales, and areas on the basis of different source documents analysis. Research comprising whole regions has been carried out [9-10]. Furthermore, metropolitan areas [11-12] as well as geographical regions [13-14] have been studied. For smaller areas of research, studies in protected areas [15], forested areas [16], periurban areas [17], areas of mining deposits [18], or river valleys [19] have been undertaken. But there is still little research where analysis of landscape changes and its capacity to absorb the changes is an essential study element. The impact and consequences of landscape change in the context of landscape capacity have been analysed since the late 1960s. The first studies in the United States were aimed at determining the land's ability to absorb specific change, with the use of the VAC (visual absorption capability) coefficient. This method has been developed and adapted to new needs, in particular with respect to forest landscapes [20].

Recently, landscape change calculations have been made especially for assessing tourism potential [21], ecosystem services [22], or spatial and land use planning [17]. In this context, research into landscape capacity was undertaken by Leitão [23] and Jacobs [24]. Also in the UK in 2003, the Countryside Agency and Scottish Natural Heritage laid down the criteria for evaluating landscape capacity [25], which are still used, and are frequently part of landscape studies conducted prior to drawing up planning documents. Assessment of landscape capacity has since been the subject of numerous studies not only in Britain but also in other European countries, being related mainly to the location of photovoltaic [26] and wind energy parks [27]. In recent years, it has also become an element of research on ecosystem services [28-30]. In Poland, evaluation of landscape capacity has also been studied in some contexts; it has been defined as landscape visual sensitivity [31], landscape absorption [32], or landscape susceptibility to change [33] and it is also used in some spatial planning documents.

In terms of landscape quality, the municipality of Sobotka is one of the most attractive areas, being located in close proximity to Wroclaw, the largest city in Lower Silesia. More than half of the municipal area is placed within the protected area of Slezanski Landscape Park and its buffer zone, which makes it a popular location for new buildings, especially for summer houses. However, when the protected park was created in the late 1980s, it triggered many conflicts. The attractiveness of the area in the Sleza Range in conjunction with the current land-use policy of the municipal authorities of Sobotka, developed on the basis of circumstances and conditions as well as directions of urban planning, pose a real threat to the landscape [34]. This is also confirmed by Hełdak's and Raszka's research [35-36]. This is why it is essential for administrative-level decisions concerning construction at particular locations to be preceded by detailed analysis. Regrettably, in Poland one is not obliged to assess how much landscape can be transformed in the land-use planning process and specific methods of assessment are non-existent, which entails the landscape being subject to uncontrolled change. This state of affairs makes us seek new solutions. Assessing landscape capacity can serve as a tool for supporting spatial planning. It shows the extent to which a particular landscape is able to absorb further changes in its spatial structure without losing its existing visual qualities.

The first stage of assessing landscape capacity is analysis of changes in land cover in different periods, as presented in this article. The significance of these studies is increasing, especially in the context of the high-value landscape protected as a landscape park, defined as an area protected because of its natural and scenic value and remaining in economic use. The main goal of my analysis was to determine the level of landscape change in the municipality of Sobotka in the years 1938-2016, and to identify the areas potentially most threatened by future transformations. The main goal was divided into specific objectives:

1. To define the area of the five basic types of land cover determining the background landscape on the basis of maps prepared for the three analysed periods: 1938, 1977, and 2016

2. To assess and determine the level of landscape change in the two periods: from 1938 to 1977 and from 1977 to 2016 by means of the landscape change index (LCI), and identify the areas of the highest level of landscape change

3. To identify how much the landscape of Sobotka municipality is threatened by changes by determining the LCI for the data on the final land cover after implementation of spatial planning documents

Assessing changes in the landscape that have occurred thus far was carried out on the basis of the land cover database and cartographic studies showing spatial distribution of land cover in the three analysed periods. On the other hand, analysis of possible future destructive changes was carried out by studying spatial planning documents depicting the spatial policy of the municipal authorities.

\section{Material and Methods}

\section{Study Area}

The municipality of Sobotka was the area of study. The municipality lies in the central part of Lower Silesia in Poland, in the district of Wroclaw, partially within Sleza Landscape Park and Bystrzyca Valley Landscape Park 


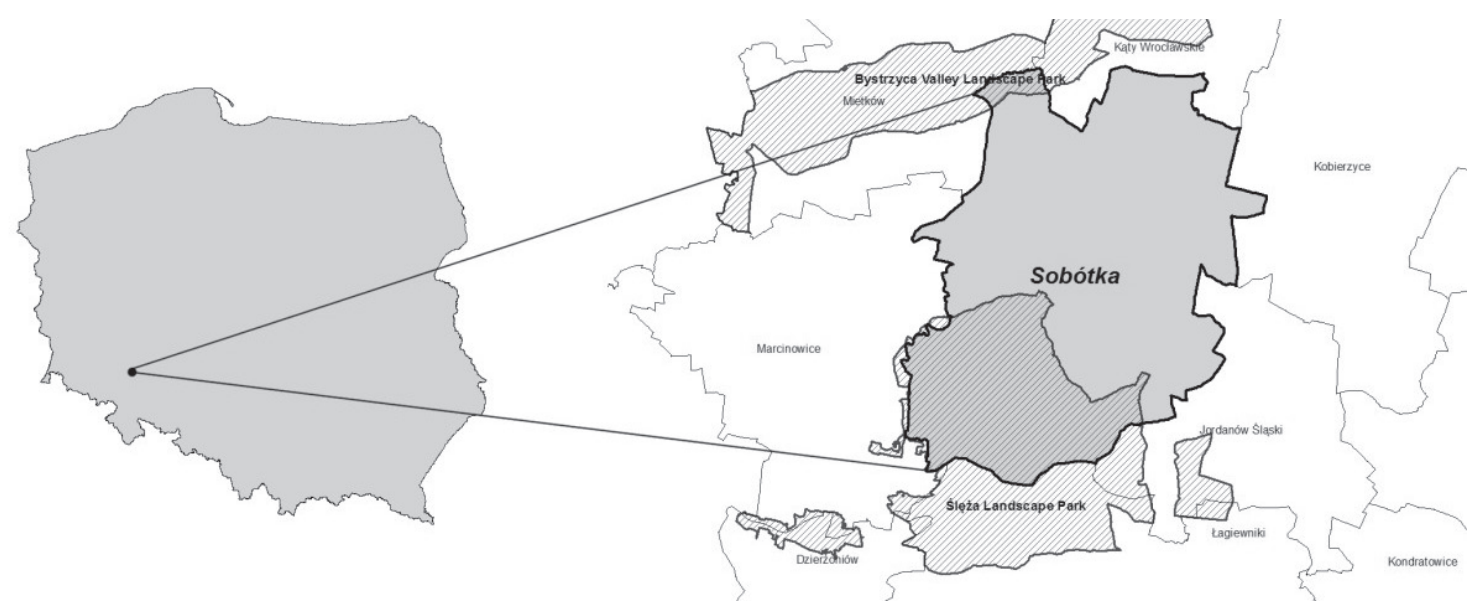

Fig. 1. Location of study area (source: own elaboration).

(Fig. 1). Located in the central part of the municipality, at the foot of Mount Sleza, the town of Sobotka is the main administrative and service centre. It lies $35 \mathrm{~km}$ southwest of Wroclaw. The settlement network is made up of 22 villages and two hamlets. The study area covers 13,535 ha (including the town of Sobotka, 3,220 ha). In 2016 the municipality had a population of 12,824 . The population density per $1 \mathrm{~km}^{2}$ was 94 inhabitants. The municipality lies in two geographic mesoregions: Wroclaw Plain in the northeast and the Silesian Lowlands macroregion; the remaining area being the Sleza Range, part of the foreland of the Sudetes. Some parts of the Sleza Range, for instance the Radunia Group and the Kielczynski Hills as well as part of the Oleszenskie Hills, cover some areas outside the municipality of Sobotka. The landscape culminates in the summit of Sleza $(718 \mathrm{~m}$ above sea level), while the lowest point, near Siedlakowice on the Czarna Woda River, is situated at a height of $143 \mathrm{~m}$ above sea level.

The municipality of Sobotka has a varied landscape. The flat northeastern part of the municipality is dominated by agricultural land. This is mostly arable land with some meadows and pastures. Forests and meadows are located mainly in the mountainous southwestern part of the municipality, in the Sleza Landscape Park and in river valleys. The area of the municipality includes one recreational reservoir and several small fishing ponds. The landscape of the municipality has been determined by intensified human intervention, primarily by progressive intensification of land use, reduction in biologically active area, and synanthropisation of vegetation. While analysing and assessing the current state of the landscape, the time factor ought to be taken into account, since elements from different periods are stored in space. It should be borne in mind that the state which can currently be observed is only a single link (at present the last one) in a long chain of transformations.

\section{Landscape Capacity Assessment}

The method for assessing landscape capacity can be used to adjust planning provisions to the current state of the landscape or for verifying planning objectives both at the stage of drawing up planning documents as well as in the case of any changes [37]. The diagram below (Fig. 2) shows particular components of assessment and stages of the procedure. First of all, past and future changes of the landscape should be determined, where transformations of

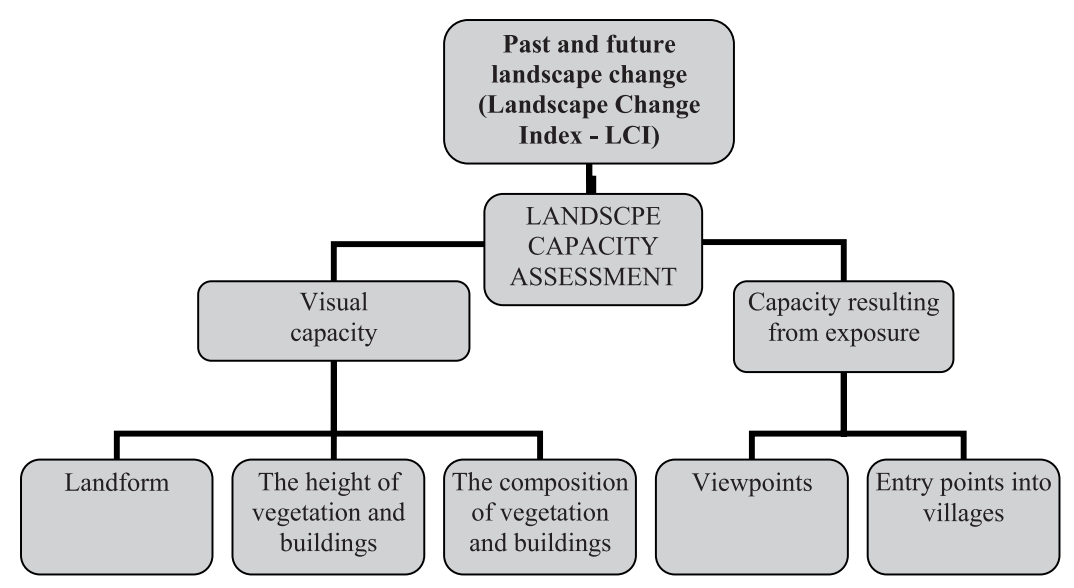

Fig. 2. Scheme of landscape capacity assessment (source: own elaboration). 
Table 1. The area of land cover types in the municipality of Sobotka in analyzed periods and spatial planning documents.

\begin{tabular}{|c|c|c|c|c|}
\hline Type of land cover & $\begin{array}{l}1938 \\
\text { (ha) }\end{array}$ & $\begin{array}{l}1977 \\
\text { (ha) }\end{array}$ & $\begin{array}{l}2016 \\
\text { (ha) }\end{array}$ & Spatial planning documents (ha) \\
\hline Forests and groves & $\begin{array}{l}2,837.7 \\
(21.0 \%)\end{array}$ & $\begin{array}{l}2,913.2 \\
(21.5 \%)\end{array}$ & $\begin{array}{l}3,036.3 \\
(22.4 \%)\end{array}$ & $\begin{array}{l}3,128.5 \\
(23.1 \%)\end{array}$ \\
\hline Meadows and pastures & $\begin{array}{c}804.2 \\
(5.9 \%)\end{array}$ & $\begin{array}{c}1,463.4 \\
(10.8 \%)\end{array}$ & $\begin{array}{l}951.3 \\
(7.0 \%)\end{array}$ & $\begin{array}{l}1,337.5 \\
(9.9 \%)\end{array}$ \\
\hline Water reservoirs & $\begin{array}{c}6.8 \\
(0.1 \%)\end{array}$ & $\begin{array}{c}15.7 \\
(0.1 \%)\end{array}$ & $\begin{array}{c}14.9 \\
(0.1 \%)\end{array}$ & $\begin{array}{c}14.0 \\
(0.1 \%)\end{array}$ \\
\hline Arable land & $\begin{array}{l}9,149.6 \\
(67.6 \%)\end{array}$ & $\begin{array}{l}8,311.3 \\
(61.4 \%)\end{array}$ & $\begin{array}{l}8,441.4 \\
(62.4 \%)\end{array}$ & $\begin{array}{l}5,909.5 \\
(43.7 \%)\end{array}$ \\
\hline Built-up area & $\begin{array}{c}736.7 \\
(5.4 \%)\end{array}$ & $\begin{array}{c}831.4 \\
(6.2 \%)\end{array}$ & $\begin{array}{l}1,091.2 \\
(8.1 \%)\end{array}$ & $\begin{array}{l}3,145.5 \\
(23.2 \%)\end{array}$ \\
\hline
\end{tabular}

(source: own elaboration)

past and future land cover in the given period of time (by definition as long as possible) is subject to analysis. Areas of the highest historical value, where the landscape has been transformed the least, will have the smallest capacity (high-priority areas for landscape protection). The second step is to assess visual capacity, which in turn determines the ability to hide zoning changes in the landscape; it is associated with topographic conditions and current land cover. The last step is to evaluate the capacity resulting from exposure; views from a specific area are analysed as well as views of that area.

\section{Analysis of Landscape Change in Research Area}

The starting point for the analysis was the claim that landscape perception is most significantly affected by two factors: landform features and land cover. Landform features hardly ever change, or the transformations are imperceptible due to the processes taking place at an extremely slow pace. The latter factor is markedly different in its nature; the changes here are very common and occur rapidly. There practically being no landform changes in the studied period, only the developments in land cover were analysed.

In order to determine the extent of changes in the landscape in the three analysed periods (1938, 1977, and 2016) I used the landscape change index [17]. It is the sum of the absolute values of the changes in the relative data of particular types of land cover, having the most significant impact upon perception of landscape, assuming that both a decrease and an increase in the area of different types of land cover alters the landscape. The data obtained helped answer the question regarding which of the analysed periods featured the greatest changes in the landscape. Assessment methodology consists of four stages:

1. Drawing up maps of contemporary and past land cover from at least three different periods of time. a)
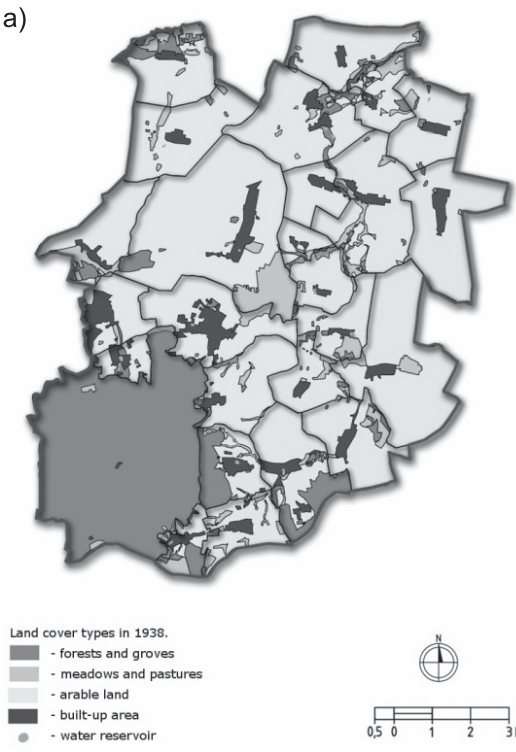

b)
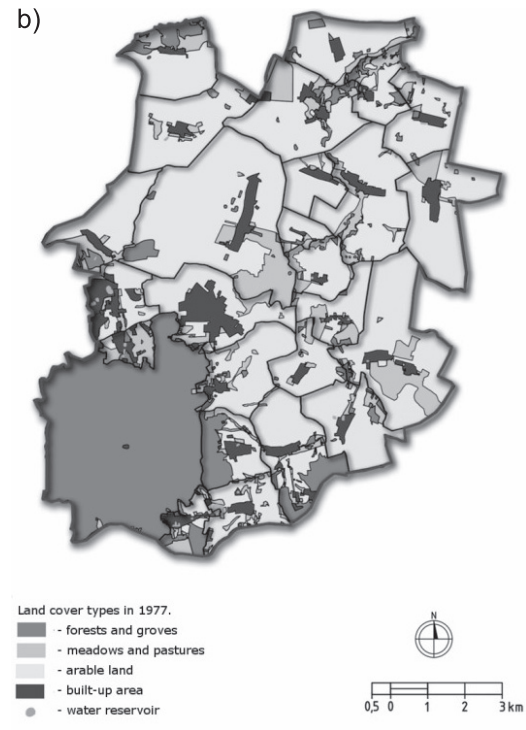

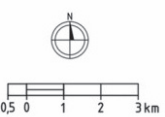

c)
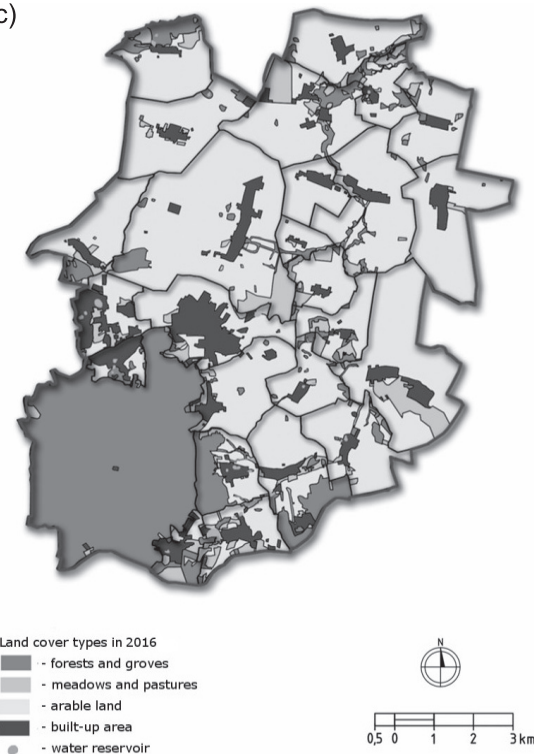

Fig. 3. Land cover maps of Sobotka Municipality in a)1938, b)1977, and c) 2016. 
On the basis of available cartographic documents, orthophotos, and field inventory, the study area was divided into five main types of land cover, which perform different functions and form the landscape backdrop: forests and groves, meadows and pastures, arable land, built-up areas, water reservoirs.

2. Prepare a database of the surface of land cover types for each of the analysed periods of time. The maps developed in the first phase provide the data.

3. Determine the percentage of deviation for each type of land cover between the benchmark (which is the first of the periods analysed) and the data from the following period. The benchmark value is equal to zero, while the deviation from the initial value by $1 \%$ in relation to the total surface area of research is equal to +1 or -1 .

4. Add up the absolute values of each degree of deviation for all types of land cover in a given period, assuming that both an increase and a decrease in value causes changes in the landscape. The resulting value is the landscape change index.

The last stage of my research was to prepare a map illustrating the target condition of land cover after implementing spatial planning documents. The map provided the basis for analysing the surface of land cover types and identifying the areas most threatened by change.

\section{Results and Discussion}

Landscape changes within the municipality of Sobotka are primarily associated with intense urbanization of attractive rural areas, which in the past several years have been affecting larger and larger areas. In order to illustrate the condition of land cover in each period, three maps were drawn; moreover, a map of land cover following the implementation of the provisions included in spatial planning documents was drawn. Tabulation of the analyses (Table 1) shows a gradual slight increase in the areas of woodland and forest. Another notable change was a significant decrease in arable land in the years 1938-77, which was largely converted into meadows and pastures (including an airfield for gliders). During this period, one can also observe a slight change in the number of built-up areas (Fig. 3).

The second analysed period (1977-2016) was marked by a slight increase in arable land and a consistent increase in built-up areas, mainly at the expense of meadows and pastures. While comparing the data from 2016 and the data obtained from the analysis of the local land use policy (Fig. 4), rapid reduction in arable land area of over 2,530 hectares and almost a three-fold increase in the surface area of built-up areas can be seen. It ought to be noted that the population of the municipality according to the data of the Central Statistical Office was 12,824 in 2016 and, according to planning documents, the projected population in 2020 for the whole area of the municipality will be 13,000. The largest increase in built-up areas can be seen especially in the geodesic area of Sobotka, Gorka, and Strzeblow, which are parts of today's administrative boundaries of the town of Sobotka.

The landscape change index (Table 2) shows that the most extensive change in the landscape occurred in the municipality from 1938 to 1977, when fields were transformed into meadows and pastures. In the years $1977-$ 2016, developments in the landscape were less significant. On the other hand, the landscape change index calculated for the status after implementation of the land use policy included in the spatial planning documents is much higher. For each of the 22 geodesic areas within the municipality of Sobotka, the LCI was also determined. On the basis of the landscape change index, the study area was divided into three classes: areas of high, medium, and low landscape change (Fig. 5).
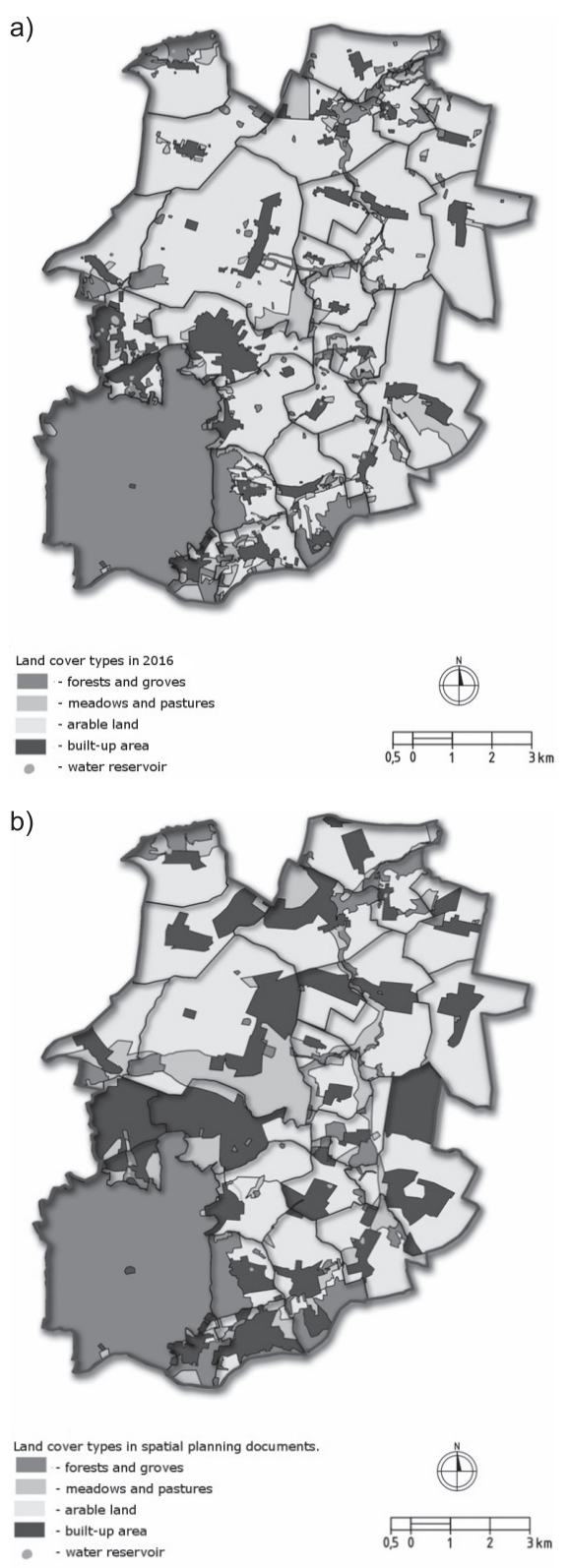

Fig. 4. Land cover map of Sobotka Municipality in 2016 and the map after the implementation of local land use policy included in spatial planning documents. 
Table 2. The percentage of deviation for types of land cover between the benchmark and the data from the following period. Landscape change index.

\begin{tabular}{|c|c|c|c|c|c|c|}
\hline & $\begin{array}{c}\text { Forests } \\
\text { and groves }\end{array}$ & $\begin{array}{c}\text { Meadows } \\
\text { and pastures }\end{array}$ & $\begin{array}{c}\text { Water } \\
\text { reservoirs }\end{array}$ & $\begin{array}{c}\text { Arable } \\
\text { land }\end{array}$ & $\begin{array}{c}\text { Built-up } \\
\text { areas }\end{array}$ & $\begin{array}{c}\text { Landscape } \\
\text { change index }\end{array}$ \\
\hline $\begin{array}{c}\text { Deviation in period 1938-77 } \\
\text { (\%) }\end{array}$ & +0.5 & +4.9 & 0.0 & -6.2 & +0.8 & $\mathbf{1 2 . 4}$ \\
\hline $\begin{array}{c}\text { Deviation in period 1977-2016 } \\
\text { (\%) }\end{array}$ & +0.9 & -3.8 & 0.0 & +1.0 & +1.9 & $\mathbf{7 . 6}$ \\
\hline $\begin{array}{c}\text { Deviation between 2016 and } \\
\text { spatial planning documents (\%) }\end{array}$ & +0.7 & +2.9 & 0.0 & -18.7 & +15.1 & $\mathbf{3 7 . 4}$ \\
\hline
\end{tabular}

(source: own elaboration)

1. Class I - areas of low landscape change - LCI from 0.00 to 16.68 .

Seven areas were included in this category: Sleza $(\mathrm{LCI}=2.87)$, Olbrachtowice (9.84), Swiatniki (11.03), Wojnarowice $(13,08)$, Księginice Male (13.86), Michalowice (14.08), and Bedkowice (14.11)

2. Class II - areas of medium landscape change - LCI from 16.69 to 33.37 .

We have 11 areas in this class: Garncarsko (18.84), Zerzuszyce (19.16), Strzegomiany (19.17), Przezdrowice (19.88), Rogow Sobocki (20.99), Stary Zamek (22.59), Krzysztalowice (24.55), Strachow (29.34), Okulice (30.75), Siedlakowice (31.71), and Kunow (31.87)

3. Class III - areas of high landscape change - LCI from 33.38 to 50.06 .

Eight areas were included in this category: Strzeblow (37.28), Miroslawice (38.21), Rekow (41.31), Sulistrowice (43.27), Sulistrowiczki (46.29), Sobotka (49.01), Naslawice (50.06), and Gorka (140.47)
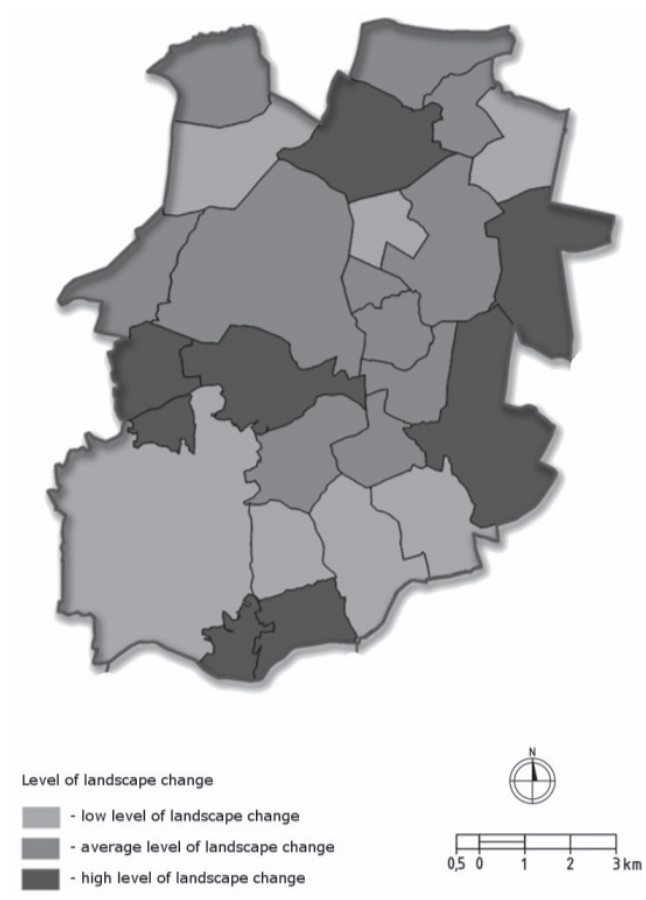

Fig. 5. Level of landscape change.
In the last decade, an intensive growth of landscape change research was noticeable. This also refers to various areas in Poland. Skowronek et al. [38] analysed changes in the rural landscape by studying two villages in mideastern Poland from the time they were founded up to now. Changes in the landscape of metropolitan areas in the period from 1950 to 1990 were studied by Solon [39]. Adamiak [40] presented intriguing results of his analysis of changes in the landscape in areas of high natural value in combination with the effect of urban sprawl and the appearance of second homes of rich city dwellers. My analyses allow us to determine the level of landscape changes in the municipality of Sobotka and indicate the periods when these changes were more intense with the use of the LCI. These transformations have been constant, and are still noticeable. This indicator is defined by Woodward and Fuhlendorf [41] as the total change in vegetation and land use at the landscape level by combining the absolute average changes of all cover types into one value. This was used to compare changes in the landscape in the states of Oklahoma, Texas, and New Mexico in the United States. To determine the current level of landscape transformation within the municipalities in the region of Wielkopolska in Poland, Lowicki [9] used an index of landscape transformation defined as the ratio of biologically active area where natural processes are dominant to the area where anthropogenic processes were dominant. In both cases, the index makes the comparison of the landscape change level of different areas much easier. The use of the LCI may supplement and improve the studies of the driving forces of landscape change, which are becoming an increasingly popular research topic [42-44]. There is still an observable shortage of examples of this type of research in some EU countries, including Poland [45]. If this kind of approach is adopted, knowledge of the periods with the most intense landscape changes is required.

\section{Conclusions}

Analyses have been showing a steadily increasing number of built-up areas since 1938 in the studied area. New areas have been acquired mainly at the expense of arable land. This is due to intense urbanization of 
attractive areas in close proximity to urban areas, which in the last couple of years has comprised larger and larger areas; in addition, agriculture has become less profitable. Determining LCI made it possible to identify the areas of unchanging landscape that should be protected, as well as landscape that has been most affected by changes so far. The highest historical value have the areas of Sleza, Olbrachtowice, Swiatniki, Wojnarowice, Księginice Male, Michalowice, and Bedkowice, while Sulistrowice, Sulistrowiczki, Sobotka, Naslawice, and Gorka have been changed the most so far. Analysis of the local land use policy as well as directions of urban planning show further changes in landscape elements, e.g., reduction of arable land across the municipality by $30 \%$. This is considerably at variance with the increase in the number of inhabitants in the municipality, which again suggests that the spatial policy of the municipal authorities is carried out contrary to the current needs of society. Planning such large builtup areas may lead to villages connecting with each other and creating a closed circle of built-up area around Mount Sleza. This rapid increase in built-up areas, despite economic benefits for the municipality and indirectly for its inhabitants, in the long term may affect the quality of their life due to landscape degradation and the shrinking of generally available natural space with recreational and leisure qualities as well as a reduction in rural landscape quality.

\section{References}

1. CETIN M., SEVIK H. Evaluating the recreation potential of Ilgaz Mountain National Park in Turkey. Environmental Monitoring and Assessment, 188, 52, 2016.

2. AMICI V., MACCHERINI S., SANTI E., TORRI D. VERGARI F., DEL MONTE M. Long-term patterns of change in a vanishing cultural landscape: A GIS-based assessment. Ecological Informatics, 37, 38, 2017.

3. ANTROP M. Landscape change and the urbanization process in Europe. Landscape and Urban Planning, 67 (1-4), 9, 2004.

4. KRAJEWSKI P. Role of landscape audit in the context of functioning principles of selected protected areas. Problems of Landscape Ecology, 43, 63, 2016 [In Polish].

5. ANTROP M. Why landscapes of the past are important for the future. Landscape and Urban Planning, 70 (1-2), 21, 2005.

6. BÜRGI M., HERSPERGER A.M., SCHNEEBERGER N. Driving forces of landscape change - current and new directions. Landscape Ecology, 19, 857, 2004.

7. CHMIELEWSKI T.J. System of spatial planning harmonizing nature and economy. Lublin University of Technology, 2001 [In Polish].

8. CETIN M. Determination of bioclimatic comfort areas in landscape planning: A case study of Cide Coastline. Turkish Journal of Agriculture-Food Science and Technology, 4 (9), 800,2016

9. ŁOWICKI D. Land use changes in Poland during transformation: case study of Wielkopolska region. Landscape and Urban Planning, 87 (4), 279, 2008.

10. WAN L., ZHANG Y., ZHANG X., QI S., NA X. Comparison of land use/land cover change and landscape patterns in
Honghe National Nature Reserve and the surrounding Jiansanjiang Region, China. Ecological Indicators, 51, 205, 2015.

11. MARULL J., PINO J., TELlO E., CORDOBILlA M.J. Social metabolism, landscape change and land-use planning in the Barcelona Metropolitan Region. Land Use Policy, 27, (2), 497, 2010.

12. DEGÓRSKA B., DERĘGOWSKA A. Changes in the landscape of metropolitan area of Warsaw at the turn of the XX and XXI century. Institute of Geography and Spatial organization, Polish Academy of Sciences, 2008 [In Polish].

13. EITER S., POTTHOFF K. Landscape changes in Norwegian mountains: Increased and decreased accessibility, and their driving forces. Land Use Policy, 54, 235, 2016.

14. DEGÓRSKA B. The transformation of the landscape of eastern Kujawy in the context of changes in land use and settlement (1770-1970). SEDNO Publishing Company, 2015 [In Polish].

15. NOGUEIRA TERRA T., FERREIRA DOS SANTOS R., CORTIJO COSTA D. Land use changes in protected areas and their future: The legal effectiveness of landscape protection. Land Use Policy, 38, 378, 2014.

16. SZABÓ P. Driving forces of stability and change in woodland structure: A case-study from the Czech lowlands. Forest Ecology and Management, 259 (3), 650, 2010.

17. KRAJEWSKI P., Landscape changes in selected suburban areas of Bratislava (Slovakia), In Landscape and Landscape Ecology - proceedings of the $17^{\text {th }}$ International Symposium on Landscape Ecology, Halada L., Bača A., Boltižiar M, Institute of Landscape Ecology, Slovak Academy of Sciences, 110, 2015.

18. FAGIEWICZ K. Spatial processes of landscape transformation in mining areas (Case study of Opencast Lignite Mines in Morzysław, Niesłusz, Gosławice). Pol. J. Environ. Stud. 23 (4), 1123, 2014.

19. BÖSE M., BRANDE A. Landscape history and man-induced landscape changes in the young morainic area of the North European Plain - a case study from the Bäke Valley, Berlin. Geomorphology, 122 (3-4), 274, 2010.

20. YEOMANS W.C. A proposed biophysical approach to Visual Absorption Capability (VAC), In Our National Landscape - a conference on applied techniques for analysis and management of the visual resource, Elsner G, Smardon R., Nevada, 172, 1979.

21. CETIN M. Evaluation of the sustainable tourism potential of a protected area for landscape planning: a case study of the ancient city of Pompeipolis in Kastamonu. International Journal of Sustainable Development \& World Ecology, 22 (6), 490, 2015.

22. TOLESSA T., SENBETA F., KIDANE M. The impact of land use/land cover change on ecosystem services in the highlands of Ethiopia. Ecosystem Services, 23, 47, 2017.

23. LEITÃO A.B. Landscape capacity evaluation and visual impacts simulation. A GIS approach. Proceedings of the $12^{\text {th }}$ European ESRI User Conference, Copenhagen, 1997.

24. JACOBS M., Making sense of environmental capacity, Council for the Protection of Rural England, London, 1997.

25. SWANWICK C. Landscape character assessment guidance. Topic paper 6: Techniques and Criteria for Judging Sensitivity and Capacity. Countryside Agency, Cheltenham and Scottish Natural Heritage, Edinburgh, 15, 2003.

26. CARULLO L., RUSSO P., RIGUCCIO L., TOMASELLI G. Evaluating the landscape capacity of protected rural areas to host photovoltaic parks in Sicily. Natural Resources, 4, 460, 2013. 
27. VAN ROMPAEY A., SCHMITZ S., KESTELOOT CH., PEETERS K., MOENS B., VAN HEMELRIJCK H., VANDERHEYDEN V., LOOPMANS M., VANDEN BROUCKE S. Landscape capacity and social attitudes towards wind energy projects in Belgium. Belgian Science Policy, 2011.

28. BALTHAZAR V., VANACKER V., MOLINA A., LAMBIN E.F. Impacts of forest cover change on ecosystem services in high Andean mountains. Ecological Indicators, 48, 63, 2015.

29. BURKHARDT B., KROLL F., MÜLLER F., WINDHORST W. Landscapes' capacities to provide ecosystem services - a concept for land-cover based assessments. Landscape Online, 15, 1, 2009.

30. BEZÁK P., BEZÁKOVÁ M. Landscape capacity for ecosystem services provision based on expert knowledge and public perception (Case study from the Northwest Slovakia). Ekológia (Bratislava), 33, 344, 2014.

31. RYGIEL P. Landscape visual sensitivity - its use in spatial planning. Technical Transactions, 5-A, 257, 2007 [In Polish].

32. OZIMEK P., OZIMEK A. Evaluation of lansdcape absorption using spatial digital model. Science Nature Technologies, 3 (1), 13, 2009 [In Polish].

33. ROZENAU-RYBOWICZ A., SZLENK-DZIUBEK D. Method of assessing landscape susceptibility to change the experience from Poronin commune. Problems of Urban Development , 1 (2), 108, 2009 [In Polish].

34. KRAJEWSKI P., RASZKA B. Spatial planning as a threat to suburban landscape. Infrastructure and Ecology of Rural Areas. 10, 85, 2011 [In Polish].

35. HEŁDAK M., RASZKA B. Evaluation of the Spatial Policy of a Commune with Regard to Planned Land Use, Pol. J. Environ. Stud. 22 (1), 125, 2013.

36. HEŁDAK M., RASZKA B. Prognosis of the Natural Environment Transformations Resulting from Spatial Planning Solutions. Pol. J. Environ. Stud. 20 (6), 1513, 2011.

37. KRAJEWSKI P. Assessment of landscape capacity as a supporting tool for spatial planning. Infrastructure and Ecology of Rural Areas. 2/1, 17, 2012 [In Polish].

38. SKOWRONEK E., KRUKOWSKA E., SWIECA A., TUCKI A. The evolution of rural landscapes in mid-eastern Poland as exemplified by selected villages. Landscape and Urban Planning, 70 (1-2), 45, 2005.

39. SOLON J. Spatial context of urbanization: Landscape pattern and changes between 1950 and 1990 in the Warsaw metropolitan area, Poland. Landscape and Urban Planning, 93 (3-4), 250, 2009.

40. ADAMIAK CZ. Cottage sprawl: Spatial development of second homes in Bory Tucholskie, Poland. Landscape and Urban Planning, 147, 96, 2016.

41. WOODWARD A.J., FUHLENDORF S.D. Influence of landscape composition and change on lesser prairie-chicken (Tympanuchus pallidicinctus) populations. Amer. Mid. Natural, 145, 261, 2001.

42. HERSPERGER A., BÜRGI M., Driving forces of landscape change in the urbanizing Limmat valley, Switzerland. In Modelling Land-Use Change, Koomen et al. (eds), Springer, 45, 2007.

43. SKOKANOVÁ H., FALTÁN V., HAVLIČEK M., Driving forces of main landscape change processes from past 200 years in Central Europe - differences between old democratic and post-socialist countries. Ekológia (Bratislava), 35 (1), 50, 2016.

44. LEVERS C., BUTSIC V., VERBURG P.H., MÜLLER D., KUEMMERLE T., Drivers of changes in agricultural intensity in Europe. Land Use Policy 58, 380, 2016.

45. PLIENINGER T., DRAUX H., FAGERHOLM N., BIELING C., BÜRGI M., KIZOS T., KUEMMERLE T., PRIMDAHL J., VERBURG P.H. The driving forces of landscape change in Europe: A systematic review of the evidence. Land Use Policy, 57, 204, 2016. 